\title{
Peertechz
}

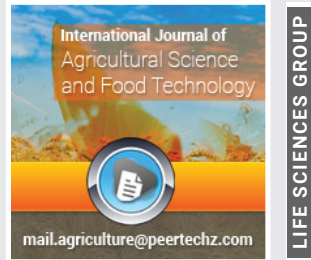

Review Article

\section{Sorghum breeding in Ethiopia: Progress, achievements and challenges}

\author{
Werkissa Yali* and Temesgen Begna \\ Ethiopian Institute of Agricultural Research, Chiro National Sorghum Research and \\ Training Center, P.O. Box 190, Chiro, Ethiopia
}

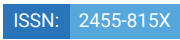

Received: 30 December, 2021

Accepted: 18 January, 2022

Published: 20 January, 2022

*Corresponding author: Werkissa Yali, Ethiopian Institute of Agricultural Research, Chiro National Sorghum Research and Training Center, P.O. Box 190, Chiro, Ethiopia,Email: workissayali@gmail.com

Keywords: Sorghum; Production; Yield; Constraints; Improvement

Copyright License: (c) 2022 Yali W, et al. This is an open-access article distributed under the terms of the Creative Commons Attribution License, which permits unrestricted use, distribution, and reproduction in any medium, provided the original author and source are credited.

https://www.peertechzpublications.com

\section{Check for updates}

\section{Abstract}

Sorghum is a critical crop especially in semiarid areas where there is inadequate moisture.it is the fifth important crop among the cereals. Sorghum is a C4 plant which is originated and diversified in Ethiopia. It is used for feed, fuel, and consumed by human beings in the form of enjera, boiled porridge or gruel, malted beverages, beer, popped grain, and chips. In Ethiopia, biotic, socioeconomic, and abiotic restrictions limit sorghum production and productivity. Drought, Striga, disease, insect pests and etc are major problems Sorghum breeding program Melkassa Agricultural Research Center, which is part of the Ethiopian Agricultural Research Institute, is in charge of coordination in Ethiopia. National and regional sorghum improvement programs have released many open-pollinated and hybrid sorghum varieties for Ethiopia's various agro-ecological zones. Nowadays to feed the world population the production and productivity of sorghum should be increased. As a result, the aim of this review is to evaluate the progress, successes, and challenges of sorghum production and productivity in Ethiopia.

\section{Introduction}

Sorghum [Sorghum bicolor (L.) Moench; 2n=20] is one of Ethiopia's most stable and varied food crops. Sorghum is the world's fifth most important cereal crop, after maize, rice, wheat, and barley [1]. In terms of acreage and production, it ranks third among cereals. Its importance as a source of food for rural populations feeds for a burgeoning cow population, and raw material for industries and construction is growing. Furthermore, because sorghum is a $\mathrm{C}_{4}$ plant, it is the heart of dryland agriculture in the current scarcity crisis. Sorghum is primarily a self-pollinating monocotyledon crop, with spontaneous cross-pollination levels ranging from 5 to $30 \%$ depending on panicle type [2].

In comparison to other food crops, sorghum is an ideal crop for dryland farming agriculture because of its vast flexibility and tolerance to unfavorable circumstances [3]. According to Mindaye, et al. [4], Ethiopia is the world's sixthlargest sorghum producer and Africa's third-largest sorghum producer, after Nigeria and Sudan [5]. After teff and maize, it is the third most important crop in terms of area covered and overall production. According to the CSA, (2018) data from the total grain crop area $81.31 \%(10,358,890.13$ hectares), sorghum cover $14.13 \%(1,829,662.39$ ha) and total production $15.70 \%$ $(50,243,68072 \mathrm{~kg})$. Sorghum is grown and cultivated nearly in all regions of the country.

Sorghum is among the most important essentials for the world's poorest and most vulnerable people [6]. Sorghum is a major food crop around the world. Alongside the content of carbohydrates, it holds iron, protein, and vitamin B3 which are greater than rice and maize. It is suitable for a specific nutritional diet because sorghum contains low gluten and glycemic index content [7]. Its grain is consumed in the forms in Africa such as injera, bread, boiled porridge or gruel, malted beverages, beer, popped grain, and chips [8].

Ethiopia, according to Vavilov [9], is the center of sorghum origin and diversification. Following the United States, Mexico, Nigeria, Sudan, and India, the country is the sixth greatest sorghum producer in the world. Sorghum is grown on roughly 
1.83 million hectares of agricultural land in Ethiopia, with a total yield of 4.34 million tons per year (FAOSTAT, 2017). According to the CSA (2016), sorghum is the third most important food crop in Ethiopia, behind maize and tef, in terms of a total number of producers, area coverage, and grain production, and is frequently used to make local bread, Injera, and different local beverages such as tela and areke. It's also eaten as a roasted vegetable and a boiled grain. Sorghum stalks are also utilized as animal nutrition, construction, and fencing materials.

Sorghum crop production is hindered by biotic, socioeconomic, and abiotic constraints. The parasitic weed Striga hermonthica and the stem borer (Chilo partellus) are the most damaging biotic restrictions $[10,11]$. According to various authors, optimal crop production and productivity in Ethiopia have yet to be achieved due to a number of socio-economic constraints, including a lack of financial support, a lack of farmer preferred varieties, a lack of improved seed systems, a lack of market linkage, a lack of value addition, a lack of extension service support, and a lack of storage facilities [10]. The most major abiotic restrictions influencing sorghum production, including in Ethiopia, are drought, poor soil fertility, and soil salinity $[10,12]$.

Melkassa Agricultural Research Center (MARC), which is part of the Ethiopian Agricultural Research Institute, is the coordinator of the sorghum breeding program in Ethiopia (EIAR). In terms of overall duties for the formulation and execution of country-wide sorghum research projects, Melkassa Agricultural Research Center (MARC) is the center of excellence for sorghum research or houses of sorghum improvement. The sorghum breeding program's activities, notably multi-location variety trials, are carried out at various federal and regional research centers and testing locations, higher learning institutions, and farmers' fields under the canopy of this institutional architecture[13]. Many openpollinated and hybrid sorghum varieties have been introduced by national and regional sorghum improvement projects for Ethiopia's moisture deficiency lowland areas [14]. Generally, the aim of this review is to state the progress, achievements, and major problems of sorghum breeding in Ethiopia.

\section{Review literature}

\section{Origin of sorghum and growing areas in Ethiopia}

Sorghum's geographic origin and preliminary domestication, according to Vavilov [9] and Doggett [2], is in Africa. Ethiopia is thought to be the genesis and domestication hub for sorghum [Sorghum bicolor (L.) Moench] from African countries. Domestication of farmed sorghum began in northeastern Africa. Due to the great variety of the crop, Vavilov proposed Ethiopia as a middle of origin for sorghum [9].

Sorghum is grown in 13 of Ethiopia's 18 major agroecological zones and 41 of the 49 sub-agro ecological zones [15]. Because Ethiopia is one of the sorghum's founding countries, it is endowed with a richness of genetic variation, as evidenced by the variety of morphological kinds grown in the country and the crop's extensive agro-ecological coverage [2]. It is grown in Ethiopia at a variety of elevations and rainfall conditions. Sorghum is grown in many of the hot, arid lowlands, and certain varieties are even grown in the cooler, wetter highlands up to 2,700 meters in height. Sorghum is typically the sole crop grown in dry lowland places where rainfall is scarce [16].

\section{Production status and economic significance of sor- ghum in Ethiopia}

Cereals are the most important food crops in the overall grain crop, according to the CSA [17] data, both in terms of planted area and production size. Because they are the primary staple crops, they are produced in greater quantities than other crops. Cereals are grown in varying quantities in all places. Generally in Ethiopia around $81.19 \%(10,538,341.91)$ hectares $)$ was under cereals. From those sorghum took up $12.94 \%(1,679,277.06$ hectares) and of the grain crop area. As to production, the Cereals contributed $88.36 \%$ (about $302,054,260.58$ quintals) of the grain production. Sorghum made up $13.22 \%(45,173,502.18$ quintals) of the grain production. It is primarily produced in Oromia, Amhara and Tigray region with their area coverage of $676,075.00$ ha, 597,440.83 ha, and $232,636.49$ ha respectively

Sorghum is the most important nutritional staple grain crop for more than 500 million people, mostly in poor nations, providing carbohydrates, vitamins, protein, and minerals [18]. Ethiopia is the world's greatest sorghum producer, followed by the United States, Mexico, Nigeria, Sudan, and India. Sorghum is grown on approximately 1,679,277.06 hectares of agricultural land in Ethiopia, with a total annual production of 45,173,502.18 quintals [1]. According to the CSA [17] data, sorghum is the third most important food cereal in Ethiopia, after maize and tef, in terms of the total number of growers, area coverage, and grain production. It is typically used to make Injera, a local bread, as well as tela and areke, the two local beverages. Sorghum is also used as feed for animals, construction, and raw material for industries.

\section{Historical perspective of sorghum breeding}

A scientific sorghum research study in Ethiopia was started in 1953 at Jimma Agricultural Technical School (JATS) now Jimma University College of Agriculture through the collection, exploration, and evaluation of sorghum germplasm [19]. Then it was moved and formal research was started in 1957 at Alemaya College of Agriculture and Mechanical Arts now Haramaya University. The establishment of the Ethiopian Sorghum Improvement Project (ESIP) in 1972 with substantial grants from the International Development Research Center (IDRC) can be considered to be the landmark of formal research on the sorghum in the country. In 1982, EIAR the then EARO assimilated ESIP as one of the national programs and took the lead of sorghum research. Since then, EIAR has been coordinating sorghum research from Melkassa Research Centre all over the country. Nowadays, the national sorghum research program is working with international, national, and regional research institutes and universities.

Currently, the breeding program identified six product

Citation: Yali W, Begna T (2022) Sorghum breeding in Ethiopia: Progress, achievements and challenges. J Agric Sc Food Technol 8(1): 045-051. 
types (PC1 - PC6) depending on the attention of sorghum growing farmers, stakeholders, and end-users 'requirements for each of the four main sorghum agro-ecologies. The resource allocation and efforts for the pipeline development aligned to the importance of the market segment for the outlined product types. The first three product types targeted the dry lowland environment, which accounted for $72 \%$ of the total area of production and the other three product types account for $8 \%$, $11 \%$, and $9 \%$ respectively for humid lowland, highland, and intermediate altitude agro-ecologies.

\section{Breeding system of sorghum}

The breeding method of sorghum employed in sorghum is generally intended to the improvement of livelihoods of smallholder sorghum farmers through the development and promotion of enhanced sorghum technologies and information/ knowledge for increased production and productivity by enhancing diet, feed, and malting quality of sorghum for industries. Because genetic variation is so important in inbreeding, the production of sorghum varieties is based mostly on germplasm enrichment, exploitation, and preservation of existing variation, or the creation of new variation. The steps in sorghum breeding pipelines start from gathering working collections (parents) for targeted traits followed by designed hybridization and management of segregating generations. Once the trait of interest has been fixed, multi-location trials will follow to evaluate and then to release a farmer preferred variety for production [20] Figure 1.

\section{Major achievements}

Despite the crop's critical importance, Ethiopia began a scientific sorghum enhancement research effort in the late 1950 s to raise yield and productivity through genetic improvement and appropriate cultural practices. According to Knife \& Tesfaye [21], more than fifty improved varieties have been released for production by several national and regional research organizations as well as universities across the country with their agronomic recommendations since the beginning Table 1.

\section{Challenges of sorghum improvement and production}

A multitude of abiotic and biotic factors have lowered sorghum's potential output. Drought and low soil fertility (nutrient deficiency) are two of the most frequent abiotic stresses. Important biotic constraints include the parasitic weed Striga (Striga species), foliar and panicle diseases, stem borers, and shoot fly [11].

\section{Drought}

Drought is one of the most serious issues influencing crop output around the planet. Droughts will become more common as a result of climate change, especially in Africa's droughtprone regions. Water problems, for example, are anticipated to affect 67 percent of the world's population by 2050 [22]. Drought is more likely in the dry and semi-arid tropics at the beginning and end of the growing season. Drought stress early in the growing season has a considerable impact on plant establishment, whereas drought stress later in the growing season might lead to reduced establishment, yield, or crop failure [23].

Many sorghum-growing areas in Ethiopia are subject to recurring droughts due to rainfall scarcity and/or unequal distribution. Rain comes late or ends early in sorghum-

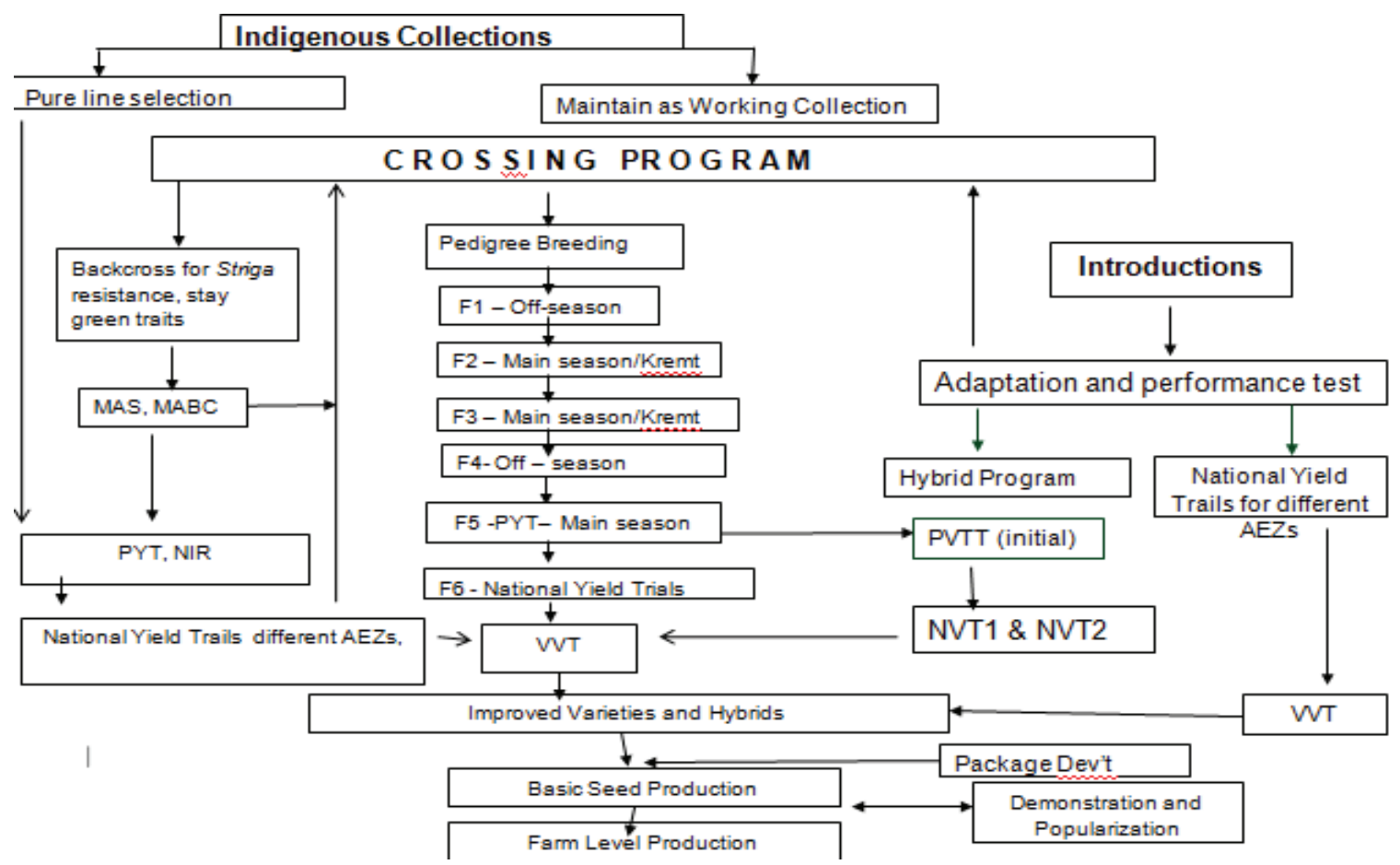

Citation: Yali W, Begna T (2022) Sorghum breeding in Ethiopia: Progress, achievements and challenges. J Agric Sc Food Technol 8(1): 045-051. DOI: https://dx.doi.org/10.17352/2455-815X.000144 
Table 1: Lists of released sorghum varieties Ethiopian.

\begin{tabular}{|c|c|c|c|c|c|c|c|c|c|}
\hline SN & Variety & Year released & Altitude & Center released & Flowering date & Height(cm) & $\begin{array}{c}\text { Yld(Q/Ha), } \\
\text { Station }\end{array}$ & $\begin{array}{l}\text { YId(Q/Ha) } \\
\text { farm }\end{array}$ & Seed color \\
\hline 1 & Gambell 1107 & 1976 & Dry Low Land & MARC/EIAR & $80-90$ & $150-200$ & $30-50$ & 25 & White \\
\hline 2 & 76T1\#23 & 1976 & Dry Low Land & MARC/EIAR & $60-70$ & $120-140$ & $25-45$ & 17 & White \\
\hline 3 & Seredo & 1986 & Dry Low Land & MARC/EIAR & $65-75$ & $110-140$ & $20-40$ & 17 & White \\
\hline 4 & Meko-1 & 1998 & Dry Low Land & MARC/EIAR & $61-92$ & $157-177$ & $22-33$ & 17 & White \\
\hline 5 & Abshir & 2000 & Dry Low Land & MARC/EIAR & 83 & $110-140$ & $15-25$ & & White \\
\hline 6 & Gobiye & 2000 & Dry Low Land & MARC/EIAR & 80 & $110-140$ & $19-27$ & & White \\
\hline 7 & Teshale & 2002 & Dry Low Land & MARC/EIAR & $65-76$ & $170-210$ & $26-52$ & & White \\
\hline 8 & Macia & 2007 & Dry Low Land & MARC/EIAR & $55-60$ & $135-150$ & $42-44$ & $23-30$ & White \\
\hline 9 & Redswazi & 2007 & Dry Low Land & MARC/EIAR & $55-60$ & $120-153$ & $30-33$ & $20-21$ & Red \\
\hline 10 & Melkam & 2009 & Dry Low Land & MARC/EIAR & $76-82$ & $126-163$ & $37-58$ & $35-43$ & White \\
\hline 11 & ESH-1 & 2009 & Dry Low Land & MARC/EIAR & $71-78$ & $160-243$ & $50-55$ & $35-45$ & White \\
\hline 12 & $\mathrm{ESH}-2$ & 2009 & Dry Low Land & MARC/EIAR & $61-75$ & 150-192 & $42-60$ & $35-43$ & White \\
\hline 13 & Dekeba & 2012 & Dry Low Land & MARC/EIAR & 75 & 136 & $37-45$ & $26-37$ & White \\
\hline 14 & Pac 537 & 2013 & Dry Low Land & GCT/MARC & 75 & 136 & $37-45$ & $26-37$ & White \\
\hline 15 & ESH-3 & 2014 & Dry Low Land & MARC/EIAR & $62-78$ & $132-170$ & $43-53$ & - & White \\
\hline 16 & ESH-4 & 2016 & Dry Low Land & MARC/EIAR & 67 & 120 & 42 & - & Red \\
\hline 17 & IS 9302 & 1983 & Intermediate & MARC/EIAR & $87-120$ & $100-180$ & $30-60$ & 25 & Red \\
\hline 18 & Dinkimash & 1986 & Intermediate & MARC/EIAR & & $103-150 \mathrm{~cm}$ & & & \\
\hline 19 & Birmash & 1989 & Intermediate & MARC/EIAR & $147-181$ & $129-178$ & $35-69$ & 20 & Red \\
\hline 20 & Baji & 1995 & Intermediate & MARC/EIAR & $147-181$ & $139-164$ & $35-56$ & 20 & Red \\
\hline 21 & Geremew & 2007 & Intermediate & MARC/EIAR & 103 & 170 & 49 & 40 & Red \\
\hline 22 & Dagem & 2011 & Intermediate & MARC/EIAR & 87 & 156 & $27-54$ & 42 & Brown \\
\hline 23 & Al-70 & 1970 & High Land & MARC/EIAR & $120-130$ & $250-384$ & $30-55$ & 33 & White \\
\hline 24 & ETS 2752 & 1978 & High Land & MARC/EIAR & $130-140$ & $243-285$ & $30-56$ & 36 & White \\
\hline 25 & Chiro & 1998 & High Land & MARC/EIAR & $130-140$ & 234-315 & $42-58$ & 38 & Red \\
\hline 26 & Chelenko & 2005 & High Land & MARC/EIAR & $124-131$ & $250-410$ & $29-64$ & & Red \\
\hline 27 & Dibaba & 2015 & High Land & MARC/EIAR & $120-140$ & $290-320$ & $37-50$ & $30-40$ & Brown \\
\hline 28 & Jiru & 2016 & High Land & MARC/EIAR & $117-144$ & $239-389$ & $33-86$ & $32-44$ & Brown \\
\hline 29 & Adelle & 2016 & High Land & MARC/EIAR & $123-149$ & $255-356$ & $37-72$ & $30-40$ & White \\
\hline 30 & Bonsa & 2017 & Intermediate & MARC/EIAR & 111.7 & 168.1 & 50 & 43 & brown \\
\hline 31 & Argiti & 2017 & Lowland & MARC/EIAR & 79.4 & 200 & 37.82 & 21 & White \\
\hline 32 & Yeju & 2002 & Dry Low Land & SARC/ARARI & 68 & 172 & 50.9 & & White \\
\hline 33 & Birhan & 2002 & Dry Low Land & SARC/ARARI & 63 & $106-167$ & 40 & & Brown \\
\hline 34 & Abuare & 2003 & Dry Low Land & SARC/ARARI & $67-80$ & $134-156$ & $26-57$ & 26 & White \\
\hline 35 & Hormat & 2005 & Dry Low Land & SARC/ARARI & 71 & $161-171$ & 23.3 & $16-22$ & White \\
\hline 36 & Mesay & 2011 & Dry Low Land & SARC/ARARI & $65-79$ & $137-231$ & $38-62$ & & White \\
\hline 37 & Raya & 2007 & Dry Low Land & SARC/ARARI & 82 & 185.7 & 37.68 & 22.77 & White \\
\hline 38 & Misikir & 2007 & Dry Low Land & SARC/ARARI & 76 & $123-191$ & 40.73 & 37 & White \\
\hline 39 & Girana-1 & 2007 & Dry Low Land & SARC/ARARI & 75 & $135-305$ & 40.86 & 38.7 & White \\
\hline 40 & Dano & 2006 & Intermediate & BARC/OARI & 132 & 350 & $40-50$ & $30-48$ & Orange \\
\hline 41 & Lalo & 2006 & Intermediate & BARC/OARI & 129 & 300 & $40-52$ & $35-48$ & Red \\
\hline 42 & Chemeda & 2013 & Intermediate & BARC/OARI & 120 & 290 & 32 & 25 & Creamy \\
\hline 43 & Gemedi & 2013 & Intermediate & BARC/OARI & 115 & 287 & 33 & 28 & yellow \\
\hline 44 & Muyra-1 & 2000 & High Land & $\mathrm{HU}$ & $100-140$ & & $30-65$ & & Red \\
\hline 45 & Muyra-2 & 2000 & High Land & $\mathrm{HU}$ & $100-140$ & & $30-65$ & & White \\
\hline 46 & Fendisha-1 & 2015 & High Land & $\mathrm{HU}$ & 147 & 332 & 63 & & Red \\
\hline 47 & Adukara & 2015 & Humid Low Land & AARC/EIAR & $148-154$ & 161 & $35.6-41.6$ & $30-30.6$ & Red \\
\hline 48 & Assosa 1 & 2015 & Humid Low Land & AARC/EIAR & $138-144$ & 260 & $35.3-41.3$ & $27.6-33.3$ & White \\
\hline 49 & Abamelko & 2001 & Intermediate & JARC/EIAR & $90-100$ & 250 & 75 & 50 & Brown \\
\hline 50 & Emahoy & 2007 & Humid Low Land & PARC/EIAR & $73-78$ & $220-300$ & $40-45$ & & Red \\
\hline 51 & Chare & 2011 & Dry Low Land & DBARC/ARARI & 73 & 192 & 42 & 33 & White \\
\hline 52 & GEDO & 2007 & Dry Low Land & Early & 75 & $116-138$ & 34 & $27-36$ & White \\
\hline
\end{tabular}

Source: Kinfe and Tesfaye [21] and some unpublished personal communication

Citation: Yali W, Begna T (2022) Sorghum breeding in Ethiopia: Progress, achievements and challenges. J Agric Sc Food Technol 8(1): 045-051 DOI: https://dx.doi.org/10.17352/2455-815X.000144 
producing regions, resulting in a crop growing time that is too short, resulting in crop failures. Drought-prone sections of the country have been made vulnerable by an unpredictable rain pattern combined with a year's subsistence agriculture system, resulting in acute malnutrition and famine [24].

Traditional agricultural practices in Ethiopia's lowlands rely entirely on a rain-fed food production system, which is characterized by poor crop performance and low yields. Low yields are caused by moisture stress, low soil fertility, Striga hermonthica, and a lack of availability to improved seed and effective production procedures. The variable rainfall patterns are the most important factor determining crop productivity in the region. Rainfall is insufficient, its distribution is inconsistent, and its onset is uncertain [22].

Drought is a severe limitation in sorghum crop production around the world, and it is regarded as the most important source of yield decrease in agricultural plants [25], particularly in water-stressed locations like eastern and southern Africa. Drought can strike at any stage of development, including seedling, pre-flowering, and post-flowering, and has the greatest impact on production [26]. Drought stress during the seedling stage will have a significant impact on plant establishment [27]. If it happens during the pre-flowering, blooming, or grain filling periods, it can lead to lower yields or even crop loss [28]. Drought tolerance has been studied as pre-and post-flowering stress, and the response of genotypes to these stresses is diverse and mediated by many genetic pathways [29].

Currently, researchers are investigating numerous growth characteristics, physiological, biochemical, and agronomic performances of distinct stay-green sorghum accessions in order to improve crop genotypes for drought-prone areas. Ethiopian sorghum landraces have native drought resistance genetic variation that has not been harnessed in the production of sorghum cultivars resistant to these critical conditions [30]. Because Ethiopia has such a large genetic pool of droughttolerant landraces, the breeding strategy in Ethiopia has mostly concentrated on screening landraces and varieties in drought-prone areas. For example, dry lowland locations such as Werer, Kobo, and Miesso were utilized to verify droughttolerant landraces or varieties before they were released [14].

\section{Weeds}

In agricultural production, weeds are an issue. They have the potential to reduce crop output. They compete with crops for resources like moisture, nutrients, space, and light, and they can also harbor pests and diseases that harm crops [31]. Weed management in grain sorghum is problematic due to a limited number of herbicides available to growers, rotational crop restrictions following the use of a number of herbicides permitted for use in grain sorghum, and the growing occurrence of herbicide-resistant weeds [32].

If high yields and effective harvesting are to be accomplished, weed control in sorghum is critical; nevertheless, adequate weed control in sorghum is generally difficult to obtain. Sorghum is a small-seeded grass that grows slowly in the first several weeks after planting. Furthermore, several herbicides that are effective on maize are not effective on sorghum. Sorghum weed management is complicated by the sluggish seedling growth, as well as the limited number of herbicides and low rates that must be utilized [33].

\section{Insects}

Sorghum productivity is affected by insect pest damage. Insect pests target seeds, seedlings, whorls, blooming structures, and mature grain at various phases of growth. More than 150 insect species have been identified as sorghum pests around the world, with more than 100 of them found in Africa. In the recent decade, entomologists have focused their attention on twenty-nine significant insect families [34]. Shoot flies, midges, stem borers, and head bugs are severe insect pests in Africa, causing damage of up to $85 \%$ in some cases [35].

Sorghum yield losses are estimated to be between 11 and 49 percent in West Africa, 15 to 88 percent in east Africa, and 50 to 60 percent in southern Africa owing to stem borer infections alone. Insect damage causes an estimated $\$ 1.1$ billion in annual losses in Africa and Asia [36]. The grasshopper, green bug, sorghum aphid, shoot fly, sorghum midge, sorghum borer, and other major insect pests of sorghum include the grasshopper, green bug, sorghum aphid, shoot fly, sorghum midge, sorghum borer, and others. General integrated management for sorghum insect pests includes cultural techniques (planting date, crop rotation, and fertilization), resistant cultivars, biological control (use of pests' natural enemies), and appropriate chemical control.

\section{Disease}

Major production restrictions were identified as sorghum anthracnose, grain mold, smut, and ergot [37]. Anthracnose and other foliar disease-resistant sources have been identified in the national sorghum improvement program. Sorghum landraces from the country's western and southern regions were resistant to a variety of leaf diseases, including anthracnose. Under the national sorghum improvement program, these places are used for sorghum screening in natural conditions (hot spot areas), particularly for disease resistance breeding $[38,39]$.

Basically, the Western and South-Western areas of the country are used as hot spots for disease testing in the national sorghum improvement program's variety verification before distribution. Sorghum breeding in these agro-ecologies has been performed by the Ethiopian national sorghum research program and various regional research centers, with a focus on leaf and grain mold resistance breeding. Bako Agricultural Research Center (BARC), Asosa Agricultural Research Center (AARC), Pawe Agricultural Research Center (PARC), and Jimma Agricultural Research Center (JARC), for example, have done a lot of sorghum breeding for leaf and grain mold diseases. Only foliar and grain disease-resistant cultivars (Chemeda, Gemedi, Lalo, Dano, Adukara, Asosa-1, and Aba melko) from BARC, AARC, and JARC have been released and are in production since today (ECVR, 2014, EIA, 2014) [40,41].

Citation: Yali W, Begna T (2022) Sorghum breeding in Ethiopia: Progress, achievements and challenges. J Agric Sc Food Technol 8(1): 045-051. 


\section{Striga}

Drought and Striga weed have been identified as the most significant restrictions in Ethiopia's northern and northeastern regions (Gebretsadik, et al. 2014). Infection with Striga has resulted in a total loss of 30-50 percent of Africa's agriculture on 40 percent of its fertile land (Amudavi, et al. 2007). Striga causes large yield losses, and infestation by Striga usually results in a major yield decline, often exceeding 65 percent in densely infested regions. According to Haussmann, et al. (2000), high Striga infestation levels can result in grain production losses of up to $100 \%$ on vulnerable sorghum cultivars. According to Ejeta, et al. (2002), in extensively infested areas in Ethiopia and Sudan, losses of 65-100 percent are normal, but the total loss might occur when Striga infection is worsened by drought.

Striga causes damage to host plants by parasitism, reduced photosynthesis, and greater partitioning of photosynthates to the roots. By allelopathy, competing for nutrients, and inhibiting the expression of sorghum plants' full genetic potential, the weed reduces crop output. It attaches itself to the roots of the host plant, weakening the crop plant by robbing it of carbon assimilates, water, nutrients, and amino acids (Pageau, et al. 2003). Furthermore, striga lowers water use efficiency (Gebremedhin, et al. 2000) and has a significant impact on the host plant's water economy due to its high transpiration rates, rendering the crop particularly vulnerable to drought. Striga infestation is frequently associated with low soil fertility, which leads to poor harvests and, as a result, starvation (Ejeta, 2007).

\section{Summary and conclusion}

Ethiopia's national sorghum improvement is looking very promising. It has got research attention. It is a very important crop for food, fuel, feed, construction and etc. especially in moisture stress areas of the country. Sorghum production and productivity are hindered by many biotic (Striga, insect, birds, disease) and abiotic (a nutrient deficiency, drought, etc.) challenges. More than 52 sorghum varieties have been released to date for various ecologies with distinct sorghum features, along with multiple agronomic suggestions.

Ethiopia's population is expected to grow at an alarming rate in the future. To feed this growing population, a quick and less expensive method of variety enhancement is projected to be used, saving both time and money. To feed the country's growing population, the National Agricultural Research System should concentrate on molecular breeding technologies, which allow varieties to be enhanced in a shorter amount of time with desirable traits. Furthermore, introducing superior released materials, evaluating them across places, and then releasing them to farmers is a preferable strategy for addressing the food problem of this growing population.

\section{Acknowledgment}

I'd want to recognize all of my friends who helped me revise my article and provided constructive feedback in order to improve the manuscript's quality.

\section{References}

1. Food and Agriculture Organization (FAO) (2021) Food and agriculture data.

2. Doggett $H$ (1988) The sorghum crop. Sorghum (2nd ed). Longman group UK Limited, London, UK 368-404

3. HUANG RD (2018) Research progress on plant tolerance to soil salinity and alkalinity in sorghum. J Integr Agric 17: 739-746. Link: https://bit.ly/3FIELui

4. Mindaye TT, Mace ES, Godwin ID, Jordan DR (2016) Heterosis in locally adapted sorghum genotypes and potential of hybrids for increased productivity in contrasting environments in Ethiopia. Crop J 4: 479-489. Link: https://bit.ly/3lctvYS

5. Gebeyehu C, Bulti T, Dagnachew L, Kebede D (2019) Additive main effect and multiplicative interactions (AMMI) and regression analysis in sorghum [Sorghum bicolor (L). Moench] varieties. J Appl Biosci 136: 13877-13886. Link: https://bit.ly/3FDcZiV

6. Mekbib F (2007) Infra-specific folk taxonomy in sorghum (Sorghum bicolor (L.) Moench) in Ethiopia: folk nomenclature, classification, and criteria. J Ethnobiol Ethnomed 3: 1-18. Link: https://bit.ly/3fFUDmZ

7. Palavecino PM, Ribotta PD, León AE, Bustos MC (2019) Gluten-free sorghum pasta: starch digestibility and antioxidant capacity compared with commercial products. J Sci Food Agric 99: 1351-1357. Link: https://bit.ly/3fDoPiy

8. Legesse T (2018) Physical Measurements and Improvement Methods of Protein and Other Nutritional Quality Traits of Sorghum [Sorghum bicolor (L) Moench]. Int J Food EngTechnol 2: 10-16. Link: https://bit.ly/3AlcbhO

9. Vavilov NI (1951) The origin, variation, immunity and breeding of cultivated plants 72: 482. Link: https://bit.ly/3ql1qmA

10. Amelework BA, Shimelis HA, Laing MD, Ayele DG, Tongoona P, et al. (2016) Sorghum production systems and constraints, and coping strategies under drought-prone agro-ecologies of Ethiopia. South Afr J Plant Soil 33: 207-217. Link: https://bit.ly/3Kzyvce

11. Wortmann CS, Mamo M, Abebe G, Mburu C, Kayuki KC, et al. (2006) The atlas of sorghum production in five countries of Eastern Africa. University of Nebraska, Lincoln, USA.

12. Dessi A (2018) Cereal crops research achievements and challenges in Ethiopia. Int J Res Studies Agric Sci 4: 23-29. Link: https://bit.ly/3nGbkD0

13. Beshir B (2019) Achievements and Prospects of Agricultural Extension and Communication in Ethiopian Research system: A Review the Case of Melkassa. MERCI project TERRA project.

14. Ethiopian Institute of Agricultural Research (EIAR) (2014) Ethiopian strategy for sorghum. Country strategy document.

15. Alemu TW (2018) Identifying sorghum [Sorghum bicolor (L.) Moench] plant types adapted to moisture stress areas of Ethiopia. (Doctoral dissertation, The University of Queensland). Link: https://bit.ly/3rz2bxe

16. Taye T, Gebisa E (2019) sorghum production in transition Through Striga Management. Link: https://bit.ly/3rxD8KV

17. CSA (Central Statistical Agency) (2020) Agricultural Sample Survey report on Area and Production of Major Crops (Private Peasant Holdings 'Meher' Season): Statistical Bulletin 585. Addis Ababa, Ethiopia.

18. Mayer JE, Pfeiffer WH, Beyer P (2008) Biofortified crops to alleviate micronutrient malnutrition. Curr Opin Plant Biol 11: 166-170. Link https://bit.ly/3fFYdxr

19. Adam B, Taye T, Amare S, Alemayehu A (2019) Defining Sorghum Product Concept from Production to Processing. Link: https://bit.ly/3flgolS

20. Sinha P, Singh VK, Bohra A, Kumar A, Reif JC, et al. (2021) Genomics and breeding innovations for enhancing genetic gain for climate resilience and nutrition traits. Theoretical Applied Genetics 1-15. Link: https://bit.ly/3ryGcXc

21. Kinfe H, Tesfaye A (2018) Yield performance and adoption of released sorghum varieties in Ethiopia. Edelweiss Applied Sci Technology 2: 46-55. Link: https://bit.ly/3KoL8qo

Citation: Yali W, Begna T (2022) Sorghum breeding in Ethiopia: Progress, achievements and challenges. J Agric Sc Food Technol 8(1): 045-051. 
22. Assefa A, Shimelis H, Tongoona P, Laing M, Mengistu F (2016) Genetic diversity of lowland sorghum landraces assessed by morphological and microsatellite markers. Austra J Crop Sci 10. Link: https://bit.ly/3fEXSuJ

23. Amare S, Amare N, Taye T, Mulate Z, Kidanemaryam W, et al. (2019) Sorghum Breeding Manual. Link: https://bit.ly/3ActyBa

24. Derese SA (2017) Breeding Sorghum [Sorghum bicolor (L.) Moench] for drought tolerance and medium-maturity (Doctoral dissertation). Link: https://bit.ly/3nGdQZY

25. Fahad S, Bajwa AA, Nazir U, Anjum SA, Farooq A, et al. (2017) Crop production under drought and heat stress: plant responses and management options. Front Plant Sci 8: 1147. Link: https://bit.ly/3FHKws8

26. Verma R, Kumar R, Nath A (2018) Drought resistance mechanism and adaptation to water stress in sorghum [Sorghum bicolor (L.) Moench]. International J Bio-Resource Stress Manag 9: 167-172. Link: https://bit.ly/3lcxTqO

27. Assefa Y, Staggenborg SA, Prasad VP (2010) Grain sorghum water requirement and responses to drought stress: A review. Crop Manag 9: 1-11. Link: https://bit.ly/3GGPjvt

28. Blum A (2011) Drought resistance: is it really a complex trait? Funct Plant Biol 38:753-757. Link: https://bit.ly/3qG6h7H

29. Ejeta G, Tuinstra MR, Grote EM, Goldsbrough PB (2000) Genetic analysis of pre-flowering and post-flowering drought tolerance in sorghum. Production in Water-Limited Environments 137. Link: https://bit.ly/3tGjq2y

30. Zelalem G, Azamal H, Masresha F, Gietahun Y (2015) Growth, water status, physiological, biochemical and yield response of Stay Green sorghum (Sorghum bicolor (L.) Moench) varieties-a field trial under drought-prone area in Amhara Regional State, Ethiopia. J Agron 14: 188-202. Link: https://bit.ly/3tFxcT5

31. Tibugari $H$, Chiduza $C$, Mashingaidze $A B$ (2020) A survey of problem weeds of sorghum and their management in two sorghum-producing districts of Zimbabwe. Cogent Social Sci 6: 1738840. Link: https://bit.ly/3FIKEHU
32. Thompson CR, Dille JA, Peterson DE, Ciampitti I, Prasad V (2019) Weed competition and management in sorghum. Sorghum: state of the art and future perspectives. Link: https://bit.ly/3nCBJl6

33. Jabran K, Mahajan G, Sardana V, Chauhan BS (2015) Allelopathy for weed control in agricultural systems. Crop Protect 72: 57-65. Link: https://bit.ly/3FLW6m5

34. Guo C, Cui W, Feng X, Zhao J, Lu G (2011) Sorghum insect problems and Management. J Integr Plant Biol 53: 178-192. Link: https://bit.ly/3Ks6Oll

35. Kahate NS, Raut SM, Ulemale PH, Bhogave AF (2014) Management of sorghum shoot fly. Popular Kheti 2: 72-74.

36. Okosun OO, Allen KC, Glover JP, Reddy GV (2021) Biology, Ecology, and Management of Key Sorghum Insect Pests. J Integrated Pest Management 12 4. Link: https://bit.ly/3qlfexo

37. Rooney WL, Delroy-Colins S, Klein RR, Metha PJ, Frederiksen RA, et al. (2002) Breeding sorghum for resistance to anthracnose, grain mold, downy mildew and head smuts. Sorghum and Millet Diseases 47 . Link: https://bit.ly/3546Bop

38. Kebede D, Dagnachew L, Habte N, Firew M, Gezahegn G, et al. (2021) Evaluation of selected Ethiopian sorghum genotypes for resistance to anthracnose. Eur J Plant Pathol 1-13. Link: https://bit.ly/3nEF6lh

39. Mengistu G, Shimelis H, Laing M, Lule D (2019) Assessment of farmers' perceptions of production constraints, and their trait preferences of sorghum in western Ethiopia: implications for anthracnose resistance breeding. Acta Agric Scand B Soil Plant Sci 69: 241-249. Link: https://bit.ly/3KrUykM

40. Seyoum A, Kebede Y, Assefa A, Jordan D, Mace E, et al. (2019) Sorghum Breeding Manual.

41. Gebeyehu G, Asfaw A, Taye T, Tesefaye T, Ketema B, et al. (2004) Development of sorghum varieties and hybrids for dry land areas of Ethiopia. Uga J Agri Sci 9: 594-605. Link: https://bit.ly/3nCCpqE
Discover a bigger Impact and Visibility of your article publication with

Peertechz Publications
Highlights

* Signatory publisher of ORCID

* Signatory Publisher of DORA (San Francisco Declaration on Research Assessment)

- Articles archived in worlds' renowned service providers such as Portico, CNKI, AGRIS, TDNet, Base (Bielefeld University Library), CrossRef, Scilit, J-Gate etc.

* Journals indexed in ICMJE, SHERPA/ROMEO, Google Scholar etc.

* OAI-PMH (Open Archives Initiative Protocol for Metadata Harvesting)

* Dedicated Editorial Board for every journal

* Accurate and rapid peer-review process

* Increased citations of published articles through promotions

* Reduced timeline for article publication

Submit your articles and experience a new surge in publication services (https://www.peertechz.com/submission).

Citation: Yali W, Begna T (2022) Sorghum breeding in Ethiopia: Progress, achievements and challenges. J Agric Sc Food Technol 8(1): 045-051. DOI: https://dx.doi.org/10.17352/2455-815X.000144 